\title{
Pull-Out Capacity of Granular Anchor Piles in Expansive Soils
}

\author{
Dr. P. Hari Krishna ${ }^{1}$, Dr. V. Ramana Murty ${ }^{2}$ \\ ${ }^{1,2}$ (Department of Civil Engineering, National Institute of Technology, Warangal, India)
}

\begin{abstract}
The stability of structures founded in expansive soils depends upon their pull-out capacity or resistance. The pile foundations adopted to alleviate the damages to the structures resting in these soil fail due to their inadequate pull-out capacity. In an attempt to develop a simple, easy to install and cost-effective alternative foundation system to the conventional concrete piles, the possible use of granular anchor piles below shallow footings was studied by conducting pull-out tests in the field after conducting pilot tests in the laboratory. From these studies, it is found that the pull-out resistance of granular anchor piles is more than twice the value of concrete piles in both unsaturated and saturated states. The pull-out resistance of concrete and granular anchor piles is decreased by about $32 \%$ and $25 \%$ respectively upon saturation.
\end{abstract}

Key Words - Concrete Pile,Expansive soil, Granular anchor pile, pull-out capacity, pull-out resistance

\section{Introduction}

The foundations of structures embedded in expansive soils are observed to undergo cyclic swell-shrink movements due to alternate wetting and drying of these soils $\{[1],[2]$, [3], [4], [5]\}, causing severe distress to the structures resting on these soils, especially the lightly loaded ones \{[6], [7], [8], [9], [10]\}. The approximate annual cost of damage caused by these soils to the civil engineering structures amounts to billions of dollars all over the world \{[11], [12], [4], [13]. To counter the heave of footings resting on these soils, several foundation techniques were put forth by the engineering community like sand cushion $\{[14]$, [15]\}, CNS layer [1], chemical stabilization $\{[6],[16],[17]\}$, moisture control [15], pile foundations $\{[18],[19]\}$ and under-reamed pile foundation $\{[20],[21],[22]\}$. Most of these techniques are being practiced with varied degree of success over a wide a range of climatic variation and soil properties.

Out of all the techniques available, Under -reamed pile foundation gained prominence all over the world in general and in India in particular. This foundation is based on the principle that it anchors down the structures in a stable zone of soil bed [23]. But this foundation technique is considered to be cost prohibitive one, especially for low cost structures, where the cost of the structure itself is low $\{[24],[25]\}$. Some researchers \{[26], [27], [28]\} have reported the difficulty in bulb formation and instead, suggested to opt for conventional concrete pile with an increase in length extending up to the stable zone. Small diameter concrete piles popularly known as micropiles have been increasingly used for various geotechnical applications like underpinning of foundations and also to resist tensile loads. It has been felt by researchers that these piles can be tried as a potential alternative to under-reamed piles \{[29], [30], [31], [32]\}. In the Similar grounds, some other investigators \{[33], [34], [13], [35]\} felt that the granular piles could be used to counteract the damage potential of footings resting on expansive soils, although they were originally developed to deal with the soft ground problems. However, a conventional granular pile cannot resist any pull-out load coming on to it due to its discrete particulate behaviour. Hence, the discrete particles are unified by providing a central anchorage member connected to the foundation footing and is named as granular anchor pile.

The pilot testing carried out at N.I.T. - Warangal both in the laboratory and field indicated that the granular anchor piles provided below shallow footings are effective in controlling their heave when compared to conventional concrete piles [36]. The efficiency of these granular anchor piles in reducing the heave of footings resting on expansive soils depends entirely on their pull-out capacity. Hence, in the present investigation, an attempt is made in the laboratory and field to study the pull-out capacity of granular anchor piles and is compared with that of conventional concrete piles. Tests were carried out both in unsaturated and in fully wet conditions of soil mass to estimate the loss of pullout capacity upon wetting.

\subsection{Laboratory Studies}

\section{Experimental Work}

\subsubsection{Materials Used}

In this laboratory work, the following materials are used.

Soil: The expansive soil used is a black cotton soil collected from $1.2 \mathrm{~m}$ depth below the ground surface near the north boundary of N.I.T. - Warangal campus. The soil properties are as follows.

Specific Gravity $=2.69$ 
Grain Size distribution:

Gravel $(\%)=3.0$;

Atterberg Limits:

Liquid limit $(\%)=107.0$;

IS Classification

Sand $(\%)=18.0 ;$ Fines $(\%)=79.0$

Compaction properties:

Optimum Moisture Content

Swell properties:

Free swell index $=162.0 \% ; \quad$ Swell potential $=24.0 \% \quad$ Swell Pressure $=3.4 \mathrm{~kg} / \mathrm{cm}^{2}$

Degree of expansion based on FSI $=$ High

Granular Pile Material: The materials that are used for the installation of piles are stones of particle size $6 \mathrm{~mm}$ to $10 \mathrm{~mm}$ and locally available sand of uniformity coefficient 2 to 3 . The stones and sand when used in the proportion of 2:1 by volume is expected to give well-compacted mass with sand filling the voids of stones [37]. Hence, in the present work, the stones and sand were used in the ratio of 2:1 for the preparation of granular pile.

Anchor: The central anchor used to unify the granular material, consists of a $5 \mathrm{~mm}$ thick metal plate welded to a vertical mild steel rod of $10 \mathrm{~mm}$ diameter with threading at the top.

Concrete Pile: The concrete piles of required diameter were cast using cement concrete of $\mathrm{M}_{15}$ mix.

For the pull-out tests in the laboratory, a testing tank of size $500 \mathrm{~mm}$ diameter and $900 \mathrm{~mm}$ long has been used (Fig. 1). The expansive soil was compacted in the testing tank at its optimum moisture content to achieve the maximum dry density value. The weight of the expansive soil required for the experiment has been divided into number of equal parts of $25 \mathrm{~mm}$ thick each, each part having to be compacted to the required height, ensuring that the desired unit weight has been attained.

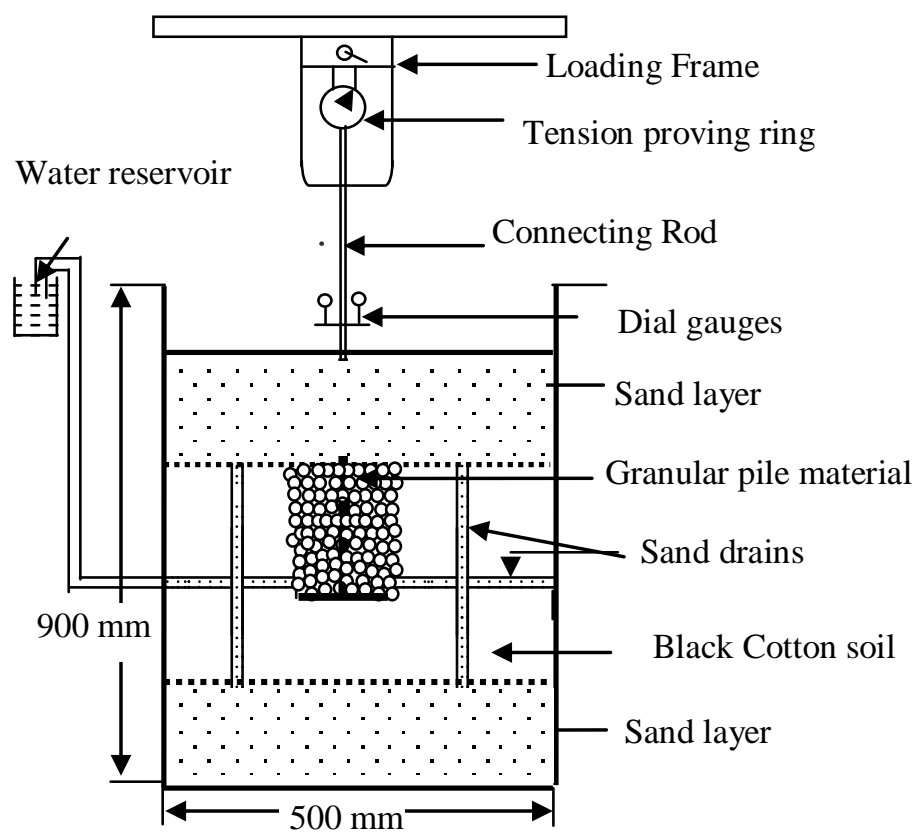

Fig. 1. Details of experimental set-up for pullout tests on granular anchor pile

To have the anchorage action of the granular pile, a mild steel circular plate of diameter equal to that of the granular pile was welded to a mild steel rod of $8 \mathrm{~mm}$ diameter and was used as an anchor at the center of granular pile. A casing pipe of diameter equal to that of granular pile has been placed at the center of the tank and the anchorage rod was inserted into the casing pipe. The black cotton soil bed was formed around the casing pipe upto a convenient height and the casing pipe was withdrawn partly (less than the thickness of the prepared soil stratum), so that a hole of diameter equal to that of granular pile was formed. Then, for the formation of granular pile, stones and sand were used in the ratio of 2:1 and the granular pile material around the central anchor member was compacted with a hammer till there is no considerable settlement. The process of preparation of soil bed and granular pile has been continued till the required height was achieved. A sand layer of $200 \mathrm{~mm}$ thick was laid over the surface of compacted soil to have the surcharge effect on it. As shown in 
Fig.1, the top end of the anchored rod was connected to a proving ring, which is attached to loading frame, and dial gauges were attached to the angles on either side of the anchor rod. Tensile load was applied on the pile (with a speed of $0.75 \mathrm{~mm} / \mathrm{min}$ ) and the proving ring readings were observed for different dial gauge readings. The test has been continued till the failure of granular anchor pile, which gives its pull-out capacity in unsaturated condition. The experimental setup used for determining the pull-out capacity in the laboratory is shown in Fig. 2.

To determine the pull-out capacity in saturated condition, the entire test setup as described earlier was prepared and the water connection was given through the inlet of the test tank and it was allowed for complete saturation. As shown in Fig.1, for easy drainage of water, sand drains were formed along the diameter and height directions, so that the saturation of the soil will be achieved quickly. During the saturation period, heave readings were observed with the help of dial gauges fixed to both sides of anchor rod and after achieving no further heave condition, pull-out load was applied on the pile to determine the pull-out capacity in saturated condition.

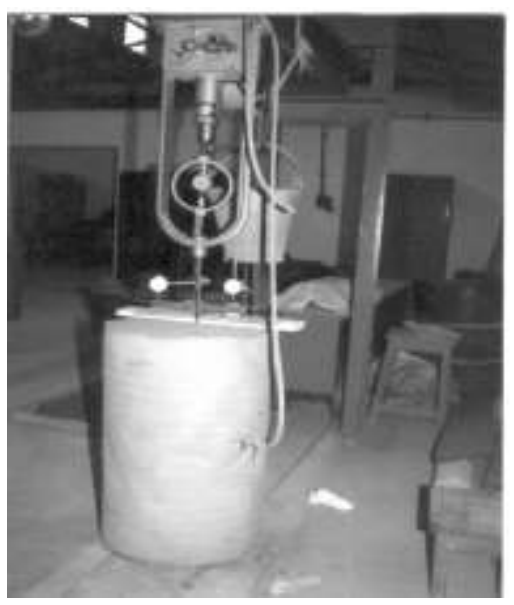

Fig. 2. Experimental set-up for pullout tests

For comparison purpose, the pull-out capacity of concrete piles of similar dimensions was determined in the same manner for both unsaturated and saturated conditions. For these tests, initially, concrete piles of $50 \mathrm{~mm}$ diameter and $200 \mathrm{~mm}$ length were cast with an anchor rod at its center using $\mathbf{M}_{15}$ grade concrete mix. These were allowed for 7 days of curing before testing them for their pull-out capacity.

\subsection{Field Studies}

For the field experimentation, the site near the north boundary of N.I.T. - Warangal campus was selected where highly expansive soil bed is available. At this site, the thickness of expansive soil is found to be around $2.4 \mathrm{~m}$ from the ground surface.

The concrete and granular anchor piles of required length and diameter were cast and installed in the field as shown in Fig. 3. The range of soil properties at this site are: Liquid limit $=70-110 \%$, Plastic limit $=26$ $-30 \%$, Shrinkage limit $=15 \%$; Clay content $=35-48 \%$; Swell potential $=12-28 \%$ and Swell pressure $=200-$ $440 \mathrm{kPa}$. It is found that the swelling properties of soil bed are increasing with depth at this site [38].

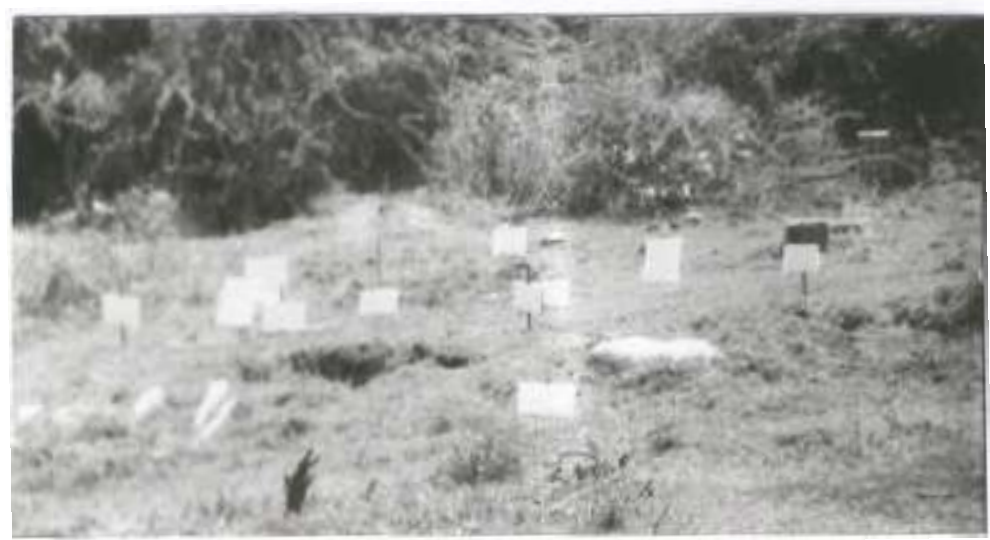

Fig. 3. Site used for pull-out studies 


\subsubsection{Types of Piles}

The following types of piles were tested for their pull-out resistance.

Granular Anchor Pile: For conducting the pull-out capacity test in the field on granular anchor piles, initially, the necessary anchorage rods of required dimensions were prepared in the laboratory. For the anchorage action, a HYSD bar of $16 \mathrm{~mm}$ diameter of required length is taken and the anchorage plate is fixed to its bottom with the help of both bolting and welding. A single rod at the center of pile has been used for the pull-out testing, and the system of granular anchor pile used is shown in Fig. 4. Using hand augers, boreholes of required diameter and depth were made in the field and these anchorage rods along with anchor plates were inserted into the boreholes. After installing these anchorage rods, the granular piles were constructed around the rods in increments of about $50 \mathrm{~mm}$. The stones and sand were poured into the borehole in the proportion of 2:1 and compacting was done with a pre-fabricated annular hammer of $20 \mathrm{~kg}$ weight falling from $0.60 \mathrm{~m}$ height. The granular pile material was compacted in lifts of $20 \mathrm{~cm}$ until the set per blow is negligible and for this, it was found that 35 blows were required for each lift. The above process was repeated till the required height of pile was achieved. The remaining portion of the borehole is filled with sand to have surcharge action on the pile.

Concrete pile: For the construction of concrete piles of various dimensions for the pull-out tests, the bore holes were filled with $\mathrm{M}_{15}$ grade concrete after placing the necessary reinforcement and was allowed for curing for about 15 days. The pull-out load was applied on these piles as in the previous case till their failure. For these piles also, the pull-out load values were measured both in unsaturated and saturated conditions for corresponding values of deformations. The system of concrete pile used is shown in Fig. 5.

\subsubsection{Pull-out testing}

The pull-out tests were carried-out both in saturated and unsaturated states. For the tests in unsaturated state, the respective piles were pulled-out immediately after their formation and the tests in saturated state were conducted after thorough wetting of the ground for about 10 days. The pull-out loads were applied using a specially devised rectangular frame for the purpose (Fig. $6 \& 7$ ).

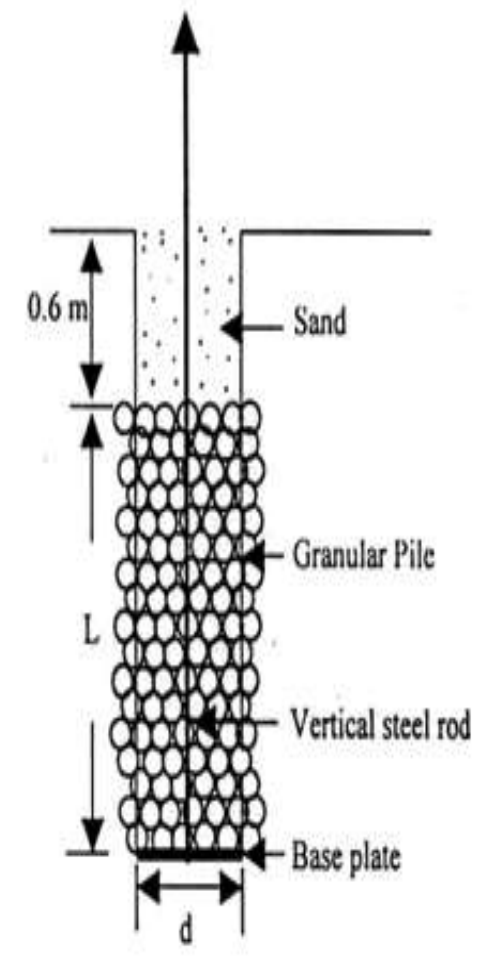

$L$ is varied as 1.0 and $1.5 \mathrm{~m}$ $d$ is varied as 100 and $150 \mathrm{~mm}$

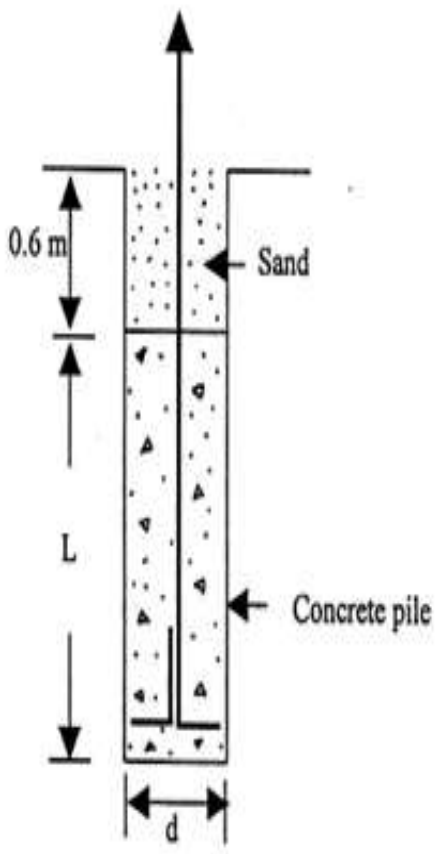

$L$ is varied as 1.0 and $1.5 \mathrm{~m}$ $d$ is varied as 100 and $150 \mathrm{~mm}$

Fig. 4. System of Granular Anchor Pile

Fig. 5 System of Concrete Pile 


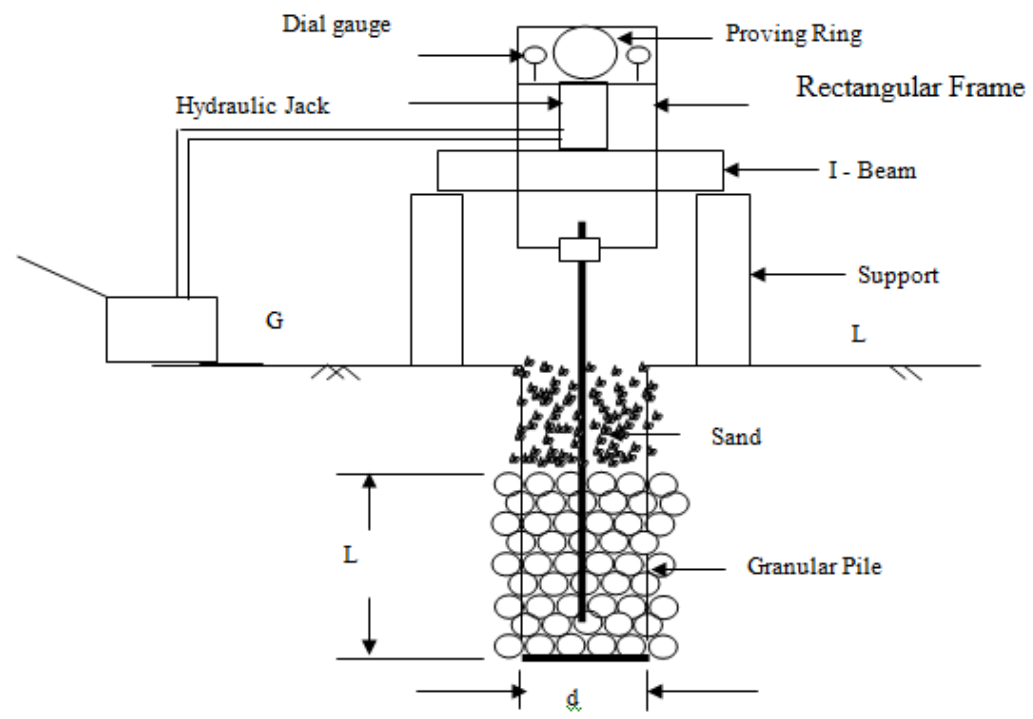

Fig. 6 Field experimental setup for determining the pullout capacity of granular anchor piles

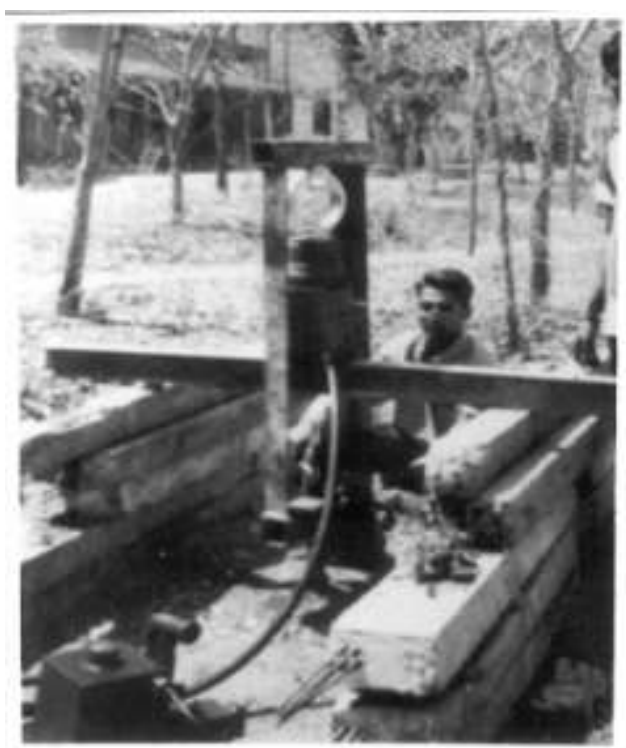

Fig. 7. Experimental set-up for in-situ pull-out capacity

\section{Discussion On Test Results}

The ultimate pull-out load or failure load for this study is defined as the load at which the granular anchor pile or concrete pile was completely pulled out or beyond which the load displacement plot became practically linear (Braja M.Das et al, 1985). The results of pullout tests in the laboratory are presented in table 1.

Table.1. Pull-out capacity of piles in the laboratory

(Diameter of pile $=50 \mathrm{~mm}$, Length of pile $=200 \mathrm{~mm}$ )

\begin{tabular}{|l|l|c|c|}
\hline S. No & \multicolumn{1}{|c|}{ Type of pile } & $\begin{array}{c}\text { Pull-out load } \\
(\mathrm{N})\end{array}$ & \multicolumn{2}{c|}{ Pull-out resistance $\left(\mathrm{kN} / \mathrm{m}^{2}\right)$} \\
\hline \multicolumn{5}{|l|}{ A. Unsaturated Condition } \\
\hline 1 & Concrete Pile (CP) & 1900 & 60.5 \\
\hline & Branular Anchor Pile (GAP) & 6600 & 210.1 \\
\hline 1 & Concrete Pile (CP) & 1700 & 54.1 \\
\hline 2 & Granular Anchor Pile (GAP) & 5300 & 168.7 \\
\hline
\end{tabular}

From this table, it can be observed that the pull-out capacity of granular anchor pile both in unsaturated and saturated conditions is about 3 to 4 times more than that of concrete pile. The load deformation curves for the pull-out tests on concrete pile and granular anchor pile are shown in Fig. 8. From these test results, it can be 
revealed that the frictional forces generated along the pile-soil surface in case of granular anchor piles are high when compared to concrete piles. This may be attributed to the ramming action in case of granular anchor piles, due to which the granular pile material will displace laterally and will mobilize maximum skin friction. In the case of concrete piles, the concrete mix is compacted by rodding/poking technique, which may not be able to displace the pile material in lateral direction effectively.

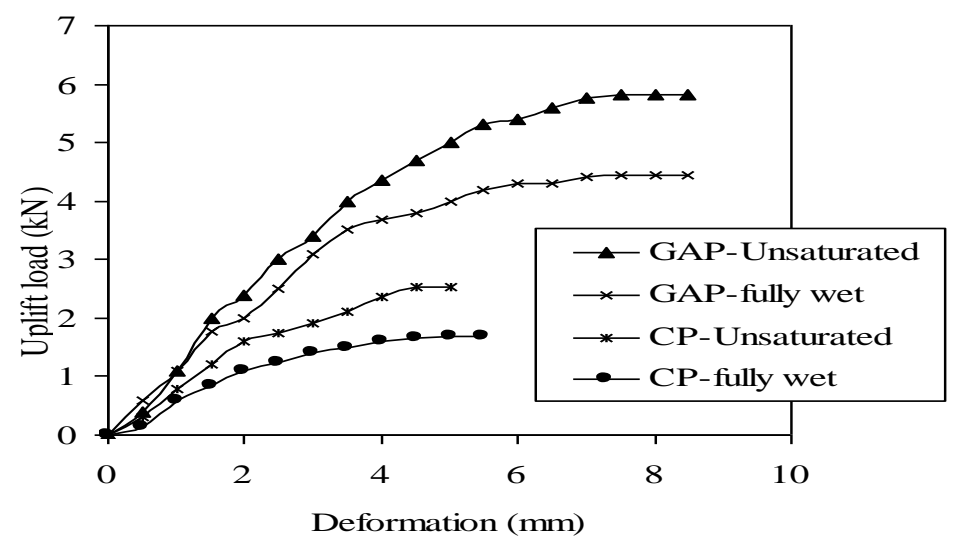

Fig. 8 Variation of uplift load with deformation of different tension piles

The results of the pullout tests on granular anchor piles and concrete piles of various dimensions in the field are presented in table 2 .

Figs. 9 and 10 show the pull-out resistance versus deformation plots for different sizes of concrete and granular anchor piles respectively. The pull-out resistance of concrete piles in unsaturated state is ranging from $70-95 \mathrm{kPa}$ whereas for granular anchor piles, it is about $200-220 \mathrm{kPa}$. The pull-out resistance of granular anchor and concrete piles is decreased by about $25 \%$ and $32 \%$ respectively upon saturation. The Pull-out resistance of granular anchor piles is more than twice the value for concrete piles both in saturated and unsaturated states. The high value of pull-out resistance for granular anchor piles could be attributed to thorough packing and lateral displacement of granular fill due to ramming. Such lateral displacement of granular fill develops close interaction and interlocking with the sides of borehole; which is questionable in case of concrete piles. Though a marginal variation in pull-out resistance of different sizes of concrete piles is recorded in unsaturated state, the size effect is negligible in saturated state for both the types of piles.

Table.2. Pull-out capacity of various piles in the field

\begin{tabular}{|c|l|l|c|c|c|c|}
\hline S1. No & $\begin{array}{c}\text { Type } \\
\text { of Pile }\end{array}$ & \multicolumn{1}{|c|}{ Condition } & $\begin{array}{c}\text { Length } \\
(\mathrm{m})\end{array}$ & $\begin{array}{c}\text { Diameter } \\
(\mathrm{m})\end{array}$ & $\begin{array}{c}\text { Uplift Load } \\
(\mathrm{N})\end{array}$ & $\begin{array}{c}\text { Uplift resistance } \\
\left(\mathrm{kN} / \mathrm{m}^{2}\right)\end{array}$ \\
\hline 1 & AGMP & Un-Saturated & 1.0 & 0.10 & 61580 & 196.0 \\
\hline 2 & AGMP & Un-Saturated & 1.5 & 0.10 & 95190 & 202.0 \\
\hline 3 & AGMP & Un-Saturated & 1.0 & 0.15 & 98140 & 208.3 \\
\hline 4 & AGMP & Saturated & 1.0 & 0.10 & 45500 & 144.8 \\
\hline 5 & AGMP & Saturated & 1.5 & 0.10 & 71160 & 151.0 \\
\hline 6 & AGMP & Saturated & 1.0 & 0.15 & 73520 & 156.0 \\
\hline 7 & CP & Un-Saturated & 1.0 & 0.10 & 22240 & 70.8 \\
\hline 8 & CP & Un-Saturated & 1.5 & 0.10 & 40010 & 84.9 \\
\hline 9 & CP & Un-Saturated & 1.0 & 0.15 & 43000 & 91.2 \\
\hline 10 & CP & Saturated & 1.0 & 0.10 & 15400 & 49.0 \\
\hline 11 & CP & Saturated & 1.5 & 0.10 & 26400 & 56.0 \\
\hline 12 & CP & Saturated & 1.0 & 0.15 & 28900 & 61.3 \\
\hline
\end{tabular}




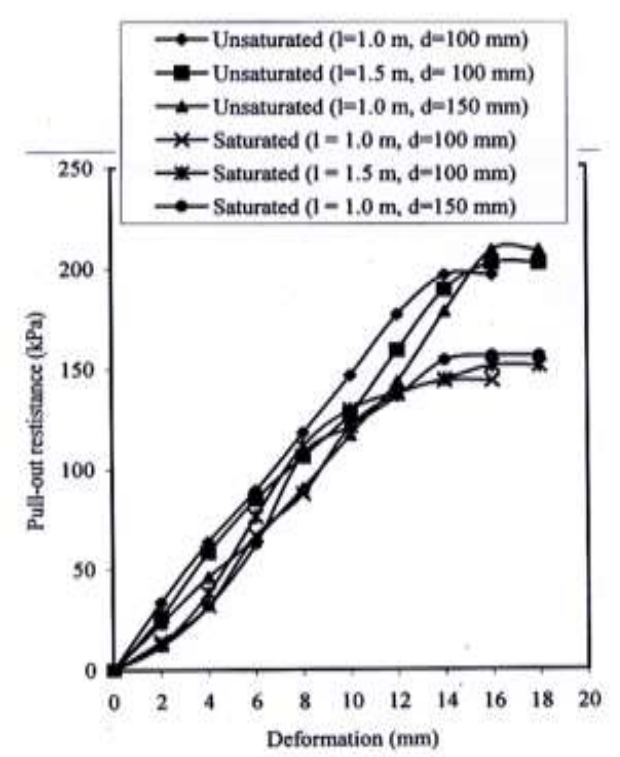

Fig.9. Pull-out Resistance $V_{B}$ Deformation Plote for Different Sizes of Granular anchor Piles

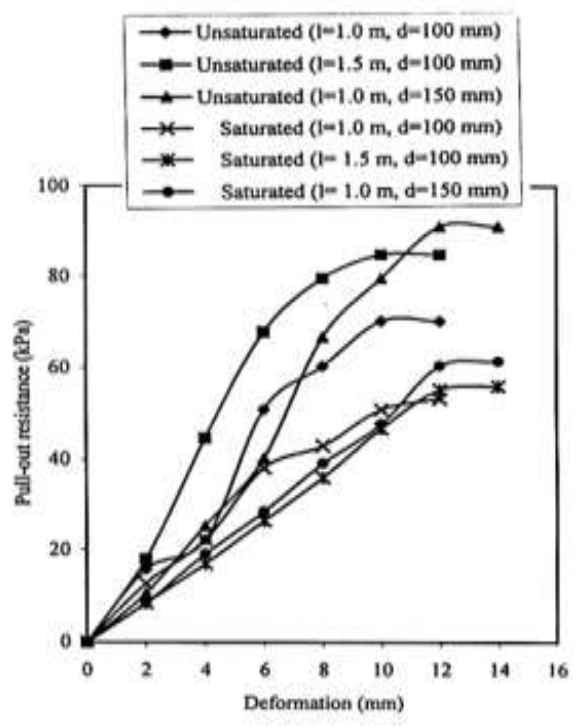

Fig. 10. Pull-out Resistance Vis Deformation Plots for Different Sizes of Concrete Piles

\section{Conclusions}

The following conclusions are made based on the investigations on the pull-out capacity of granular anchor piles.

1. The granular anchor pile is found to be a cost effective foundation treatment alternative to the conventional concrete piles for increasing the pull-out carrying capacity of foundations on expansive soil.

2. The pull-out resistance of concrete piles in unsaturated state is about $70-95 \mathrm{kPa}$ whereas for granular anchor piles, it is about $200-220 \mathrm{kPa}$. In saturated condition, the range of values for concrete piles is 49 to $61 \mathrm{kPa}$ and for granular anchor piles, it is from 145 to $156 \mathrm{kPa}$.

3. The pull out tests both in laboratory and field under both saturated and unsaturated conditions have revealed that the pull-out resistance of the granular anchor piles is around 3 to 4 times that of similar concrete piles.

4. From the laboratory test results it can be observed that on saturation, the pull-out resistance is decreasing by about $14 \%$ that of unsaturated condition in case of granular anchor piles, whereas it is decreasing by $26 \%$ in case of concrete piles. And in case of field studies, the decrease is by about $25 \%$ for granular anchor piles and by $32 \%$ for concrete piles.

5. For the same surface area, the effect of diameter on the pull-out capacity is more than that of length in increasing the pull-out resistance.

The granular anchor pile technique can be a potential treatment alternative for anchoring the footings resting on expansive soils. The performance of these granular anchor piles in controlling the heave of footings is to be further investigated for their performance before promoting them as an alternative foundation system in expansive soils in view of their effectiveness and simplicity in construction.

\section{References}

[1] Katti RK, Search for solutions to problems in black cotton soils, First IGS Annual Lecture, Indian Geotechnical Journal, 9(1), 1979, 1-80. (80)

[2] Chen, F.H. Foundations on Expansive Soils (Elsevier Pub. Co, 1988)

[3] Subba Rao, K.S. Swell-shrink behaviour of expansive soils - Geotechnical challenges, $22^{\text {nd }}$ IGS Annual Lecture, Indian Geotechnical Journal, 30(1), 1999, 1-68.

[4] Petry Thomas, M. and Little Dallas, N. Review of stabilization of clays and expansive soils in pavements and lightly loaded structures - History, practice and future, Journal of Materials in Civil Engineering, ASCE, 150 ${ }^{\text {th }}$ Anniversary paper, 2002 : $447-457$.

[5] Puppala, Anand J., Napat Inthara Sambat and Rajan K. Vempati, Experimental studies on ettringite - induced heaving in soils, Journal of Geotechnical and Geoenvironmental Engineering, ASCE, Vol.131(3), 2005, 325-337.

[6] Snethen, D.R. et. al, An evaluation of methodology for prediction and minimization of detrimental volume change of expansive soils in highway subgrades", Research Report, Vol.1, Prepared for Federal Highway Administration, Washington, 1979.

[7] Freeman, T. J., Burford, D. and Crilly, M. S. Seasonal Foundation Movements in London Clay, Proc. of $4^{\text {th }}$ International Conference Ground Movements and Structures, Cardiff, 1991, 485-501.

[8] Jie Li and Donald A Cameran, Case study of courtyard house damaged by expansive soils, Journal of Performance of Constructed Facilities, Vol.16, 2002, 169-175.

[9] Vu Q. Hung, Fredlund, G., Delwin, G. The prediction of one, two and three dimensional heave in expansive soils, Canadian Geotechnical Journal, 2004, 173-177. 
[10] Ahmed A, Assessment of drying - wetting cycles to mitigate the potential of expansive soil in Upper Egypt, Journal of Applied Science Research, 5(12), 2009, 2277-2284.

[11] Jones, D.E. and Holtz, W.G, Expansive soils - The hidden disaster, Civil Engineering, ASCE, Vol.43, No.8, 1973, 49-51.

[12] Day, R.W. Swell - shrink behaviour of expansive compacted clay, Journal of Geotechnical Engineering, ASCE, Vol.120, No.3, 1994, 618-623.

[13] Phani Kumar, B.R., Radhey S. Sharma, Sri Rama Rao, A. and Madhav, M.R. Granular pile anchor foundation system for improving the engineering behaviour of expansive clay beds, Geotechnical Testing Journal, Vol. 27, No.3, 2004, 279-287.

[14] Satyanarayana, B. Swelling pressure and related mechanical properties of black cotton soils, Doctoral Thesis., Civil Engineering Department, I.I.Sc., Bangalore, India. (1966)

[15] Sorochan, E.A. Construction of buildings on expansive soils (Oxford and IBH publishing Co. Pvt. Ltd., New Delhi, 1991).

[16] Petry, T.M. and Armstrong, J.C, Stabilisation of expansive clay soils, TRR 1219, TRB, Washington, D.C, 1989, 103-112.

[17] Amer Ali Al-Rawas, Hago, A.W. and Hilal Al-Sarmi, Effect of lime, cement and sarooj (artificial pozzolan) on the swelling potential of an expansive soil from Oman, Journal of Building and Environment, 40, 2005, 681-687.

[18] Poulos, H. G. and Davis, E. H. Pile Foundation Analysis and Design (John Wiley \& Sons, New York, 1980)

[19] Dinesh Mohan, Pile Foundations, (Oxford \& IBH Publishing Co. Pvt. Ltd., Delhi, 1991).

[20] Piven V. G. Piles with widened bases in swelling soils, Proceedings of the First National Symposium on Expansive Soils, HBTI, Kanpur, India, 1977, .4.1 to 4.4

[21] CBRI, Handbook on under-reamed and bored compaction pile foundation (Jain Printing Press, Roorkee, India, 1978).

[22] Setty, K.R.N., Ravi Shankar, A.V. and Manohar, C, Behaviour of under-reamed piles in shedi soil, Proceedings of IGC-96, Madras, India, Vol.1, 1966, 286-289.

[23] Mohan D., Jain G. S. and Sharma D, Foundation practice in expansive soils in India, Proceedings of the $3^{\text {rd }}$ Int. Conf. on Expansive Soils, Haifa, Israel, 1973, 125-132.

[24] Bhandari, R.K., Balodhi, G.R., Ramesh Chandra and Chandra Prakash, Behaviour of short bored piles in expansive soils during the stage of swelling, Proceedings of $6^{\text {th }}$ International Conference on Expansive Soils, New Delhi, India, 1987, 547-552.

[25] Phani Kumar, B.R., Prasada Raju, G.V.R. and Sri Rama Rao, A, Use of anchored granular columns in minimising swell in expansive clays, Proceedings of IGC-94, Warangal, India, 1994, 61-65.

[26] Babushanker, N., Appayanna, M.N. and Shankaraiah, B, Design and testing of under- reamed piles, Proceedings of Geotech-80, Bombay, India, Vol. 1, 1980, 203-206.

[27] Devendra Sharma, Chandra Prakash and Ramesh Chandra (1987): Two case studies of unsatisfactory performance of short bored piles, Proceedings of $6^{\text {th }}$ International Conference on Expansive Soils, New Delhi, $309-316$.

[28] Dey, A.K., Minda, R. and Gurung, K, A case study on under-reamed piles, Proceedings of 6th International Conference and Exhibition on Piling and Deep Foundations, Bombay, 1996, 4.9.1 - 4.9.4.

[29] Donaldson G.W., The Use of Small Diameter Piles in Expansive Soil, Proceedings of $4^{\text {th }}$ Regional Conference for Africa on Soil Mechanics and Foundation Engineering, Capetown, South Africa, 1967, 249-251.

[30] Ali Elfatih, M. and Abbadi Seif Eldawla, A, Design of short tension piles in expansive soils: A probabilistic approach, Proceedings of $9^{\text {th }}$ Regional Conference for Africa on Soil Mechanics and Foundation Engineering, Lagos, 1987, 307-311.

[31] Mohammed Zein, Yahia, E. A., Muzamil G. Mohammed and Ahmed M. E. I. Sharief, Finite element analysis of short piles in expansive soils, Journal of computers and Geotechnics, Elsevier, 1999, 231-243.

[32] Osama K. Nusier and Ahmed Shlash Alawneh, Micropile technique to control upward movement of lightweight structures over expansive soils, Journal of Geotechnical and Geological Engineering, No.22, 2004, 89 - 104.

[33] Rao, B.G. and Bhandari, R.K, Use of Skirted Footings in Expansive Clay, Proceedings of First National Symposium on Expansive Soils, Kanpur, 1977, 9-1 to 9-11.

[34] Pradeep Kumar, Gopal Ranjan and Swami Saran, GAP system for resistance of uplift forces, Proceedings of IGC-2003, 597-602.

[35]. Ramana Murty Varudu and Hari Krishna Padavala, Piled footings - An alternative foundation system in expansive soils, Journal of Ground Improvement, ICE, Vol. 165, Issue G13, 2012, 159-166.

[36] Hari Krishna P and Ramana Murty, V, In-situ Heave measurements of concrete and anchored granular micropiled footings, Proceedings of Indian Geotechnical Conferene, Allahabad, Pheonix publishing house, New Delhi, India, Vol.1, 2002, 377-380.

[37] Datye, K.R., Nagaraju, S.S, Installation and Testing of Rammed Stone Columns, Proceedings of IGS - Specialty Session of the $5^{\text {th }}$ ARC, Bangalore, India, 1975.

[38] Ramana Murty, V, A study on swell pressure and methods of controlling swell of expansive clays, Doctoral. thesis ,.Kakatiya University, Warangal., 1988. 